\title{
Child Witness Protection Challenges in Kenya
}

\author{
Wilson Kiprono ${ }^{1}$, Kibet Ngetichi $^{2}$, Wokabi Mwangi ${ }^{3}$ \\ ${ }^{1}$ Department of Peace, Security and Social Studies, Egerton University, Kenya \\ ${ }^{2}$ Department of Peace, Security and Social Studies, Egerton University, Kenya \\ ${ }^{3}$ Department of Peace, Security and Social Studies, Egerton University, Kenya
}

\begin{abstract}
This paper focuses mainly on the key challenges facing Child Witnesses that need to be fixed by the Witness Protection Program in Kenya. The study sought to achieve the following specific objectives: To examine parameters influencing protection of witnesses and find out if there are challenges in the Witness Protection Program with special reference to minors as witnesses. Study data was collected from Kenya's criminal Justice agencies. Two methods of data collection were used. They include: in-depth interviewing and document analysis. The number of participants was determined by those who were likely to yield information being sought. Top five informants were selected from each eight selected agencies since they are better placed to give the relevant information. The study revealed that there is lack of training resources such as facilities, training institutions and trainers. The study further found out that there are no ideal infrastructural and communication facilities suitable for minor witnesses.
\end{abstract}

Keywords: Child Witness Protection Challenges. Kenya.

\section{INTRODUCTION}

Most children who testify in criminal court are doing so about alleged activities perpetrated on them, and in particular, they are testifying about alleged abuse. The primary reason that this is the case is not because children fail to witness other crimes, but because they are simply not ideal witnesses. Additionally, the process of investigative interviewing may, for some children, is perceived as an extra stressor. In other types of crimes (e.g., theft or assault), other witnesses or other types of evidence are likely to be present and are generally preferable types of evidence to statements made by young children. Even in allegations of child physical abuse, the children's bodies can be used as corroboration of their reports, but in physical or sexual abuse cases, medical corroboration or other witnesses are generally not available. Thus, when we speak of child witnesses we are most commonly addressing concerns relevant to child physical or sexual assault cases. This study therefore explores the protection given to children in line with keeping their dignity

\section{Problem Analysis and ObJectives}

The principle of the best interests of the child is not limited to criminal justice; it is often proclaimed in a generic way, embracing all aspects of the child's life. Civil matters, including family law, are often considered the main field of application of this principle. Although it is important to apply the principle to those matters, it is crucial that domestic judges, as well as other criminal justice officials and every adult in a decision-making position, give it primary consideration when determining issues related to the involvement of child victims and witnesses in criminal proceedings.

\section{OVERVIEW OF THE CONCEPT OF CHILD WitNeSSing IN CRIMINAL JUSTICE SySTEMS}

One of the factors that affect how children react to testifying is maternal support. Children who do not receive maternal support during legal proceedings function significantly more poorly over time (Goodman et al., 1992b). Similarly, children who receive maternal support are likely to disclose sexual abuse earlier and experience less distress (Elliott and Briere, 1994; London, et al., 2005; Olafson and Lederman, 2006; Shaw et al., 2001). Previous research has found that children's perceptions of the legal process may very well be mediated by the perceptions of their caretakers (Good man et al., 1992b). Thus, it is possible that some of the anxiety that children feel about testifying and their negative feelings about the process may be a reflection of what they are hearing from their parents or sensing about their parents' emotions.

${ }^{1}$ Corresponding Author: Wilson.kiprono@gmail.com 
American Research Journal of Humanities and Social Sciences, Volume 1, Issue 3, 2015

ISSN 2378-7031

\subsection{Focus Of Kenya's Child Witness Protection}

Providing support and court preparation for child victims and witnesses, works in partnership with the justice system and the community to provide confidential support services and impartial court preparation for children and youths, 17 years of age and under, involved in the criminal justice system as victims and/or as witnesses.

\subsection{The goals of the Child Witness Program}

The major goals of Kenya's witness protection program focuses in the preparation of Child Witnesses for court facilitate truthful testimony and help protect the child/youth's sense of self-worth and confidence during this process

\subsection{Child witness protection Services}

Services provided within the program include: Assessing the specific needs of the child and advocating on his or her behalf, Educating the child on courtroom procedures and the role of a witness, helping the child cope with his/her fears and apprehensions, visiting the courtroom before going to court, helping parents to be effective in supporting their child, scheduling and attending meetings for the child with the Assistant Crown Attorney, providing updates for the family on the progress of the case advocating for "child friendly" court rooms and waiting rooms, accompanying children into the courtroom or in the closed circuit TV room and, when needed, onto the witness stand, assisting with victim impact statements, explaining the verdict and sentencing and referring the child and/or the family to community services, if needed. At no time during court preparations is a child's or youth's evidence discussed.

\subsection{Child Witness Program Expectation}

In an ideal Child Witness Program, every child called upon to testify should: Be treated with respect during his or her involvement in the criminal justice system, feel safe and protected in a courtroom, have court preparation tailored to his or her individual needs have easy access to testimonial aids, be questioned by adults who adapt their communication to his or her developmental age and linguistic ability and have his or her special needs met and vulnerabilities addressed

\subsection{Child Witness Before A Jury}

Jurors have a reasonably accurate perspective about many areas of eyewitness research, but jurors, and even judges, have misconceptions about a number of witness issues, including misconceptions about child sexual abuse. For example, both jurors and judges believe that eyewitness confidence is related to accuracy, which is often not the case (Rahaim and Brodsky, 1982). Jurors rely too heavily on minute details and underestimate the importance of effective indicators of eyewitness accuracy, such as how long the witness was able to view the perpetrator (e.g., whether the perpetrator was wearing a disguise) and what other perceptual conditions were present (e.g., was it light enough to realistically observe a detailed face?). Jurors often lack knowledge about factors that interfere with accurate retention, such as the impact of stress on perception and memory, and are insensitive to biases that are introduced during a criminal investigation (Sven-Ake, 1992). This study explores the capacity gaps with Jurors when dealing with children who are also affected by social-cultural factors.

\section{Methodology}

The study was carried out at the judicial and legal institutions within Nairobi county . The study was focused on the following institutions or departments: the Attorney General office, the Law Society of Kenya, The Directorate of Public Prosecution, the Kenya Police, The Ministry of Gender (Children's Department), Directorate of Witness Protection Agency, the Children's Court, and the representatives from the National Assembly. Secondary data was collected from case related legislative provisions and reports from national and international agencies advocating for human rights. The study considered this scope to be sufficient because most of these institutions have their headquarters within the Nairobi region, the offices in the region handle are highly influential on matters of policy formulations and implementation, and they handle the highest number of cases relating to participation of children in criminal proceedings. The Nairobi region includes the city of Nairobi (Nairobi central), Athi-River municipality, Ngong municipality, Thika municipality, Kikuyu municipality, Limuru municipality, Kiambu municipality and Ruiru municipality. This was arrived at based on the assumption that the research findings in Nairobi and surroundings easily be related to those of other areas of Kenya. Figure 1.0 below shows the map of the study area. 


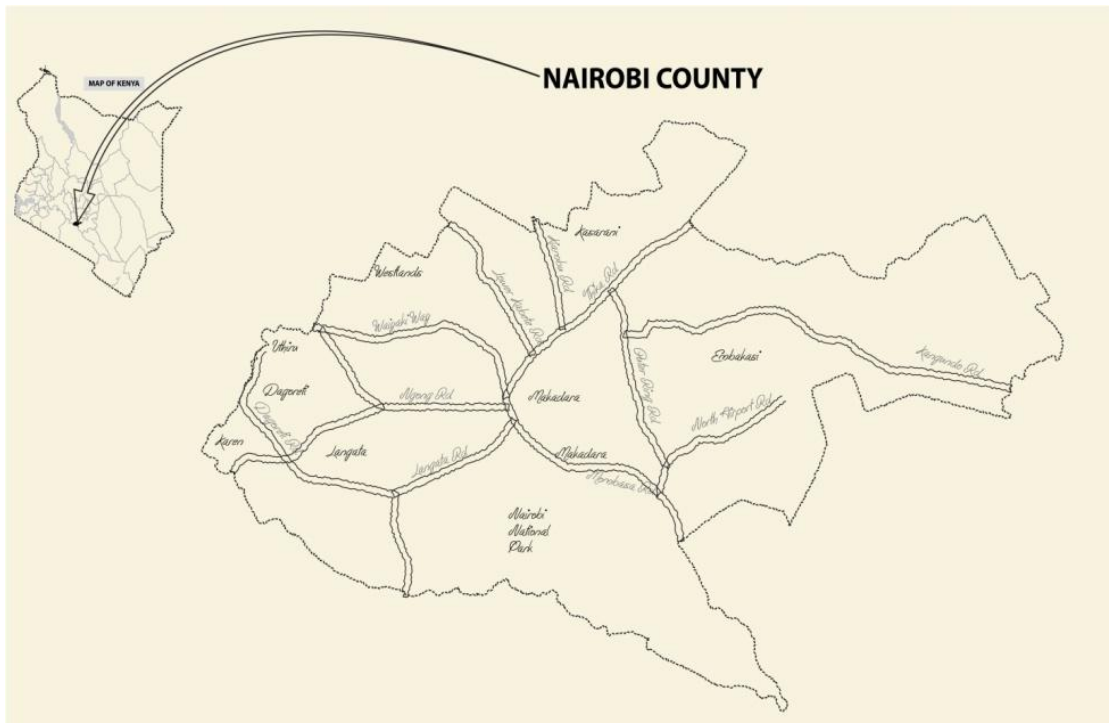

Source: Writer (2015)

The study adopted a case study design. A case study approach was necessary considering the nature of the target respondents. The research utilized a case study design and qualitative mode of inquiry. In qualitative research different types of interpretative techniques are involved, which attempt to describe and facilitate an understanding of an event in the social world. Qualitative research encompasses several types of inquiry that explain the meaning of social phenomena without disrupting the natural environment. "Case study" is a term that may be used interchangeably with qualitative research; however, there are distinct features for case studies. In a case study the investigator has less control over events. This approach is usually recommended especially when questions of "how" or "why" come up. The purpose of the research was to provide strategic implementation profiles that use descriptive, historical and interpretive methods to document the organization's experiences. The focus of the research was on the processes and challenges occurring in the implementation of the witness protection programme: its early development, its growth and changes, and the current status of the organization. In case studies the focus of the study is not necessarily to test a hypothesis, but to gather information in order to present a description of what was going on in a study environment (Ceci, et al., 1995). The required data was obtained through self-report methods, namely, in-depth interviewing and document analysis.

The study focused on 40 key informants drawn from the following: the Attorney General office, the Law Society of Kenya, The Directorate of Public Prosecution, the Kenya Police, The Ministry of Gender (Children's Department), Directorate of Witness Protection Agency, the Children's Court, and the representatives from the National Assembly. Five informants were obtained from each of the above areas.

According to Schutt (1996:593), unit of analysis is "the level of social life on which the research question is focused". The unit of analysis is thus the category across which the study's variables vary. The major units of analysis for the study were the gaps in implementation of witness protection programme in Kenya. The units of observation were the informants drawn from across various governmental agencies tasked with pursuit of justice as well as witness protection.

The sample for the study was drawn through purposive sampling. According to Kothari (2008), purposive sampling is ideal when the researcher intends to pick up subjects for the study that meet a defined criterion. The researcher applied this approach to select key informants from the Attorney General office, the Law Society of Kenya, The Directorate of Public Prosecution, the Kenya Police, The Ministry of Gender (Children's Department), Directorate of Witness Protection Agency, the Children's Court, and the representatives from the National Assembly. Being a non-probabilistic and subjective approach, the researcher intended to reach out to at most 40 key informants.

The primary data for the study was collected from the key informants drawn from the Attorney General office, the Law Society of Kenya, The Directorate of Public Prosecution, the Kenya Police, The Ministry of Gender (Children's Department), Directorate of Witness Protection Agency, the Children's Court, and the representatives from the National Assembly. The researcher would spend considerable time at offices identifying key informants (including key strategists) who were involved with the formulation of the witness protection programmes, reading the current 
and past correspondence dealing with the formulation of policies leading to the programme, and having extensive discussions with the select key informants.

Two methods of data collection were applied. They include: in-depth interviewing and document analysis. In qualitative research, the technique of in-depth interviewing is extensively used, as it facilitates an interaction with the interviewer and the interviewee with a defined objective of gathering valid and reliable data. In general, qualitative in-depth interviews are informal and less structured interviews. During the interviews, the researcher attempts to gain the participant's meaning and perspective of relevant topics. While collecting data, the researcher provides opportunities for the participants to describe their experiences and simultaneously to discuss their opinions regarding the level of success of the activities. The process of interviewing allowed the participant to describe and reconstruct details. Open-ended questions would enable the interviewee to elaborate and to recall additional information. Further, the researcher was able to lead the participant to providing more in-depth insights through these loosely structured interviews.

In the second approach of document analysis, the researcher was able to extract pertinent information from the research reports and policy papers. Historical perspectives assisted in the study of the appropriate period for the understanding of some events or processes. This time perspective was important in determining the linkages of events that created an important issue and the consequences of events. The researcher was also to use the two sources commonly cited in the data gathering literature: primary, which provide firsthand account of events; and secondary, which are reports concerning some event from third party sources.

After the fieldwork, qualitative data was analyzed through content analysis. According to Hancock (2002:17), content analysis involves coding and classifying data through categorizing or indexing. The basic idea was to identify from the transcripts the extracts of data that were informative in some way and to sort out the important messages hidden in the mass of each interview.

Ethical considerations like ensuring confidentiality of responses were assured before the data collection commences. This was necessary because it encouraged the respondents to be honest. No respondent was forced to take part in this study. The authority to visit the respective offices was sought from the respective Directorates. A research permit was also sought from the National Council for Science and technology.

\subsection{Results and Discussions}

\subsubsection{Introduction}

The broad objective of this study was to examine the challenges facing the implementation of witness protection program in Kenya. Specifically, this study sought to achieve the following objectives: investigate the capacity gaps in the Witness Protection Program and the underlying causes; establish the legal threshold and practice in the Kenya's criminal justice system that expressly protects witnesses in court; assess the infrastructure-related challenges prevailing in protection of witnesses; and to examine the socio-cultural barriers influencing protection of witnesses.

\subsubsection{General Information of the Sample}

Data for this study was collected from 40 key informants who directly handle witness protection issues. The sample was largely male-dominated with $85 \%$ of the sampled respondents being male respondents and the remainder of $15 \%$ being female. The gender distribution is shown in Table 4.1 .

Table4.1. Distribution of Sample Respondents by Gender

\begin{tabular}{|l|l|l|}
\hline Gender Category & Number of Respondents & \% of the Total \\
\hline Male & 34 & $85.0 \%$ \\
\hline Female & 6 & $15.0 \%$ \\
\hline Total & 40 & $100.0 \%$ \\
\hline
\end{tabular}

The respondents were drawn from the Attorney General's office, the Law Society of Kenya, The Directorate of Public Prosecution, the Kenya Police, The Ministry of Gender (Children's Department), Directorate of Witness Protection Agency, the Children's Court, and the representatives from the National Assembly. The researcher spent considerable time at offices identifying key informants (especially key strategists) who were involved with the 
American Research Journal of Humanities and Social Sciences, Volume 1, Issue 3, 2015

ISSN 2378-7031

formulation of the witness protection programmes, reading the current and past correspondence dealing with the formulation of policies leading to the programme, and having extensive discussions with key informants. Table 4.2 indicates the distribution of the respondents by the source institutions from where they were sampled from.

Table4.2. Respondent Distribution by Source Organization

\begin{tabular}{|l|l|}
\hline Agency & Number of Respondents \\
\hline Attorney General Office & 5 \\
\hline Law Society & 5 \\
\hline Directorate of public prosecution & 5 \\
\hline Ministry of Gender & 5 \\
\hline Directorate of witness protection agency & 5 \\
\hline Children's court & 5 \\
\hline Kenya police & 5 \\
\hline National Assembly & 5 \\
\hline Total & $\mathbf{4 0}$ \\
\hline
\end{tabular}

A majority of the sample respondents had extensive experience in civil and criminal litigation issues, public policy formulation, and legislative procedures. All respondents had over 3 years working experience in each of these three core areas under review, with a majority of the respondents (60\%) being in the 6-10 years' experience bracket. These results are tabulated in Table 4.3 below.

Table4.3. Distribution of Sample Respondents by Level of Experience

\begin{tabular}{|l|l|l|}
\hline Years of Experience & Number of Respondents & \% of the Total \\
\hline $0-2$ years & - & - \\
\hline $3-5$ years & 6 & $15.0 \%$ \\
\hline $6-10$ years & 24 & $60.0 \%$ \\
\hline Over 10 years & 10 & $25.0 \%$ \\
\hline Total & $\mathbf{4 0}$ & $\mathbf{1 0 0 . 0 \%}$ \\
\hline
\end{tabular}

\subsubsection{Shortage of Expertise and Poor Training of Personnel}

Table 4.8 presents some of the current experts seconded to the agency as well as the gap levels when compared to best practices across the globe. The results indicate that gaps are openly evident in expertise areas such as: counsellors, human rights specialists, criminologists, forensic analysts, and VIP protection. This may be attributed to the fact that the Kenya's WPA is still in the formative stages. On going skills maintenance and development is the key to the effectiveness of a witness protection programme. Protection officers perform a number of functions that require aptitudes that are different and perhaps broader than normal police functions. As a result, training must be multidisciplinary in nature and cover diverse fields. Coordinated and standardized training in national witness protection programmes could increase the confidence of the authorities in the capacity to protect witnesses.

Table4.4. Expertise Level at the WPA

\begin{tabular}{|l|l|l|l|}
\hline Expert Category & Number Available in Kenya & Number in USA & Number in South Africa \\
\hline Counsellors & 0 & 14 & 5 \\
\hline Police Constables & 8 & 26 & 16 \\
\hline Police Investigators & 22 & 52 & 32 \\
\hline System Engineers & 1 & 4 & 4 \\
\hline
\end{tabular}


American Research Journal of Humanities and Social Sciences, Volume 1, Issue 3, 2015 ISSN 2378-7031

\begin{tabular}{|l|l|l|l|}
\hline Human Rights Specialists & 0 & 8 & 6 \\
\hline Criminologists & 0 & 23 & 8 \\
\hline Forensic Analysts & 0 & 9 & 4 \\
\hline VIP Protection & 0 & 16 & 6 \\
\hline
\end{tabular}

The findings indicate that there is a severe shortage of experienced trainers in Kenya on matters of witness protection. The findings further indicate that the Kenya's WPA is populated with expertise whose background is mainly law, security, and intelligence gathering. Considering that witness protection is a new concept in the Kenyan context, the respondents were of the view that the government ought to have hired expatriates from foreign countries that have vast experience in setting up and managing witness protection programmes.

\subsubsection{Legal Basis of Child Witness Protection in Kenya}

Currently, the Witness Protection (Amendment) Act, 2010 is operational as an override Act of Parliament to amend the Witness Protection Act, 2006. The main purpose of the current Act was to establish a Witness Protection Agency and provide for its powers, functions, management and administration, and for connected purposes. However, despite the law being in place, its implementation is yet to be felt with some level of significance. In the current version of the Act child witness protection issues are given little attention.

\section{Excerpt 1.0: Case of Lack of Witness Protection for Highly Vulnerable Witnesses}

The case of a woman who was killed along with her three daughters after she gave evidence in a criminal trial in Kenya has raised the alarm about the procedures used to protect witnesses. The attack happened in April 2014 after the 45-year-old woman, Agneta Imbaya, and one of her daughters testified against a man at a court in the town of Bungoma in western Kenya. The man was on trial for a violent robbery carried out in Imbaya's home village in 2013, and he had openly threatened her and her daughter in the courtroom. He warned them that if they did not withdraw their testimony, he would exact revenge. The suspect was in custody during the trial, but was released after the case collapsed. Police believed that days later he went to Imbaya's house and murdered her and her three daughters, and went on the run. Despite the threats made against Imbaya in court, her family were not included in the national witness protection programme. The police commissioner for Bungoma County, Maalim Mohammed, defended his officers' actions. He told local media that his force had not received a report that the suspect had been released from custody, or that he posed a threat. In response to the matter, Kenya's deputy director of public prosecutions, Kioko Kamula, said that current legislation sets out clear procedures for handling such matters. Under the Witness Protection Amendment Act 2010, witnesses themselves, a law enforcement agency, a public prosecutor or a legal representative can request protective measures. Alice Ondiek, director of the national Witness Protection Agency (WPA), criticised the Bungoma court for not alerting her office to the threat made against Imbaya and her daughter. Ondiek said that courts generally do not pay enough attention to witness safety. In this instance, the suspect was released after the trial collapsed. But Ondiek noted that criminal suspects are often not remanded in custody during proceedings even if they may pose a threat to society, or are liable to abscond. The long duration of trials which often drag on for years also works against efforts to protect a witness over a sustained period of time. "Criminals have disappeared when out on bond, and others threatened the safety of witnesses when out on bail," she said.

Source: Institute of Peace and War Reporting (2014)

Findings further reveal the general position of the Kenyan law in regard to protection of witnesses in the criminal justice system, where there are witnesses as well. The respondents explained that the act provide for the protection of such witnesses by ensuring that the Agency shall consider the needs of such witnesses and where necessary assign a person to assist such a person throughout all the stages of the protection program (Sec.6 of the witness Protection Regulations).

\subsubsection{Infrastructure-related Challenges Prevailing in Protection of Witnesses}

Findings revealed that some of the challenges facing WPP are related to the infrastructure in place. The findings are tabulated in Table 4.5 below 
American Research Journal of Humanities and Social Sciences, Volume 1, Issue 3, 2015

ISSN 2378-7031

Table4.5. Infrastructure-related Challenges Prevailing in Protection of Witnesses

\begin{tabular}{|l|l|l|}
\hline Cited Challenges & Number of Respondents & \% of the Total \\
\hline Lack of isolated office blocks & 11 & $27.5 \%$ \\
\hline In adequate isolation chambers & 11 & $27.5 \%$ \\
\hline Technological systems & 7 & $17.5 \%$ \\
\hline
\end{tabular}

*Each row is based on multiple responses (out of 40 sampled informants

\subsubsection{Socio-Cultural Barriers Influencing Protection of Witnesses}

Findings reveal that socio-cultural beliefs and practices affect the implementation of the WPP. The findings are tabulated in Table 4.15 below.

Table4.6. Socio-Cultural Barriers Influencing Protection of Witnesses

\begin{tabular}{|l|l|l|}
\hline Cited Barriers & Number of Respondents & \% of the Total \\
\hline Strong cultural bonds among kinsmen & 13 & $32.5 \%$ \\
\hline Fear of possible identity change & 7 & $17.5 \%$ \\
\hline Victims/ witnesses may not be cooperative & 12 & $30.0 \%$ \\
\hline Prohibited cultural topics of discussion & 8 & $20.0 \%$ \\
\hline Perceived prohibition for women to testify & 4 & $10.0 \%$ \\
\hline Curse threat on testifying against practices & 2 & $5.0 \%$ \\
\hline
\end{tabular}

*Each row is based on multiple responses (out of 40 sampled informants)

This study also sought to identify ways in which cultural diversity influence the appearance and testifying of witnesses within the court process. The findings are tabulated in Table 4.7 below.

Table4.7. Ways in Which Cultural Diversity Influences Witness Participation

\begin{tabular}{|l|l|l|}
\hline Cited Barriers & Number of Respondents & \% of the Total \\
\hline Cultures prohibit open courts testifying & 16 & $40.0 \%$ \\
\hline Cultures prohibit women to testify & 7 & $17.5 \%$ \\
\hline Children and young men do not testify against old men & 7 & $17.5 \%$ \\
\hline Co-operation with law enforcers a taboo & 7 & $17.5 \%$ \\
\hline Tribalism: perceived tribal rivalry & 12 & $30.0 \%$ \\
\hline
\end{tabular}

*Each row is based on multiple responses (out of 40 sampled informants)

Findings from the study reveal that some socio- cultural beliefs and practices prohibited witnesses to testify in open courts especially on intimate matters and testimonies from women and youths are barriers to the witness protection program. Some barriers revealed in the study include: ethnic loyalties which prohibit one to testify against tribesman, seeking legal justice through revenge missions such as raids, glorification of illegal activities, language barrier as well as cultural prohibition of relocation from cultural land and change of identity.

\section{CONCLUSION AND RECOMMENDATION}

Formal witness protection programs offer a way to safeguard the investigation, the criminal trial, and the security of witnesses. Their main objective is to safeguard the lives and personal security of witnesses and collaborators of justice, as well as people close to them.

The programs include procedures for the physical protection of witnesses and collaborators of justice such as, to the extent necessary and feasible, relocating and re-documenting them and permitting, where appropriate, nondisclosure or limitations on the disclosure of information concerning the new identity and whereabouts of such persons. From the findings of the study, it can be concluded that there exist challenges in terms of inadequate technical staff that are not adequately trained to handle Child witnesses, to a larger extend the study revealed that 
socio cultural issues creates and sustained significant criminal justice challenges when it comes to Child witnesses. It can also be concluded that there are also inadequate infrastructural facilities in protecting the witness with non conducive court environment which are inaccessible for many witnesses.

\subsection{Recommendations}

In view of the findings of this study, the following two sets of recommendations; namely policy recommendations and areas for further research, would be appropriate

\subsubsection{Policy Recommendations}

\subsubsection{Capacity Building}

The entire key Staff deployed to work at Witness Protection should be well trained on modern technology that can improve the participation of children as witness in courts. The courts should be structured to be friendlier to children.

Suggestions were made on what the agencies engaged should do to enhance the capacity in protection of Child witnessing in Kenya. Civic educations especially to stakeholders should be done. It was also recommended that international cooperation should be enhanced. To facilitate benchmarking with international developed systems

\subsubsection{Infrastructural Development of WPP}

Criminal justice institutions should be equipped to facilitate easy access and efficiency. Government should adequately fund the program to facilitate its development and acquisition of adequate resources.

\subsubsection{Legal threshold of WPP}

The respondents were asked to give recommendations in regard to enhancement of legal threshold for protection of witnesses in Kenya. They suggested that the witness protection funds should not be under the government control. They should have the money set aside during a financial year to meet the need when a case arises. It was also suggested that there. It was also noted that the current legal provisions covering witness protection in Kenya has given little attention to Child witnessing.

\subsubsection{Socio- cultural Challenges}

Issues to be addressed in this regard include: expanding natural adhesion to fight tribalism; inculcate moral values among Kenyans; let them recognize that a crime is a crime even when perpetrated by tribesmen; trained translators to invest in equipment for example, audio and video recorders; ensure confidentiality and privacy of witnesses and victims of crime. Civic education and awareness campaign was also a major recommendation, as suggested by $62 \%$ of the respondents

\section{REFERENCES}

[1] Ceci, S. J., \& Bruck, M. (1995). Jeopardy in the courtroom: A scientific analysis of children's testimony. Washington, DC: American Psychological Association

[2] Elliott, D. M., \& Briere, J. (1994). "Forensic sexual abuse evaluations of older children: Disclosures and symptomatology". Behavioral Sciences and the Law, 12, 261-277

[3] Goodman, G. S., Taub, E. P., Jones, D. P. H., England, P., Port, L. K., Rudy, L., \& Prado, L. (1992a). Testifying in criminal court. Monographs of the Society for Research in Child Development, 57 (5, Serial No. 229).

[4] Hancock, B, (2002) Trent Focus for Research and Development in Primary Health Care: An Introduction to Qualitative Research. University of Nottingham Division of General Practice: Trent Focus.

[5] Leichtman M.D., \& Ceci S.J., (1995) “The Effects of Stereotypes and Suggestions on Preschoolers' Reports", 31 Developmental Psychology, 568, 571

[6] London, K., Bruck, M., Ceci, S. J., \& Shuman, D. W. (2005). "Disclosure of child sexual abuse: what does the research tell us about the ways that children tell?" Psychology, Public Policy, and Law, 11, 194-226

[7] Olafson, E. (2007). “Children's memory and suggestibility”. In K. C. Faller, Interviewing children about sexual abuse: Controversies and best practice (pp. 10-34). New York: Oxford University Press.

[8] Rahaim, G. L., \& Brodsky, S. L. (1982) Empirical evidence versus common sense: Juror and lawyer knowledge of eyewitnesses accuracy.

[9] Republic of Kenya (2011) Witness Protection Agency Annual Bulletin - 2010; Nairobi: WPA

[10] Schutt, R., (1996) Investigating the Social World; Thousand Oaks, CA: Pine Forge. 
American Research Journal of Humanities and Social Sciences, Volume 1, Issue 3, 2015

ISSN 2378-7031

[11] Shaw, J. A., Lewis, J. E., Loeb, A., Rosado, J., \& Rodriguez, R. A. (2001). "A comparison of Hispanic and AfricanAmerican sexually abused girls and their families". Child Abuse \& Neglect, 25, 1363-1379.

[12] Sven-Ake C., (1992) "Emotional Stress and Eyewitness Memory: A Critical Review", 112 Psychological Bulletin 284 pp. $119-131$. 